\title{
Evaluasi Penyelenggaraan Sekolah Bertaraf Internasional (SBI) di Sekolah Dasar (SD), Sekolah Menengah Pertama (SMP), Sekolah Menengah Atas (SMA), dan Sekolah Menengah Kejuruan (SMK)
}

\author{
Idris HM Noor \\ Peneliti pada Pusat Penelitian Kebijakan Balitbang Kemdiknas. \\ E-mail: idrishmnoor@yahoo.com
}

\begin{abstract}
Abstrak: Penyelenggaraan RSBI merupakan salah satu usaha pemerintah untuk meningkatkan mutu pendidikan agar mampu bersaing dengan negara lain. Sejak diselenggarakan tahun 2006, RSBI belum pernah dievaluasi secara komprehensif. Oleh karena itu, perlu dievaluasi PPDB, prestasi, pengelolaan pendanaan, dan sistem tata kelola dan akuntabilitas penyelenggaraannya. Penelitian menggunakan metode campuran kuantitatif dan kualitatif. Sampel sebanyak 4575910 yang diambil secara purposive. Responden: komite sekolah, kepala sekolah, guru bahasa Inggris, matematika, dan IPA yang mengajar di kelas RSBI dan kelas reguler. Temuan: Kemampuan bahasa Inggris pendidik dan tenaga kependidikan RSBI di semua tingkat masih level novice (skor TOEIC 10-250). Kemampuan guru bahasa Inggris kelas RSBI dan kelas reguler relatif sama. Di SD dan SMP, kemampuan siswa dan guru RSBI sedikit lebih tinggi daripada kelas regular. Kemampuan guru Biologi dan Fisika kelas RSBI di SMA lebih rendah daripada guru kelas reguler. Penggunaan dana kurang transparan. Rekomendasi, perlu peningkatan kualifikasi dan kompetensi akademik guru dan perlu disusun panduan pengelolaan pendanaan yang lebih rinci.
\end{abstract}

Kata Kunci: RSBI, PPDB, prestasi akademik, pendanaan, tata kelola.

\begin{abstract}
The implementation of pilot standard of international school (pre SIS) is one of the government's efforts to improve educational quality in order to be able to compete with other countries. Since the establishment of the pre SIS in 2006, they have not been evaluated comprehensively yet. Therefore, it is important to evaluate the student's enrolment, academic achievement, finance and budgetting, and management. Research method used is mixed quantitative and qualitative method. Samples are 4575910 respondents chosen purposively. They are school committee, school principals, teachers of pre SIS and regular classe. They are English, mahtematics, and science teachers, students, and students' parents association. The English proficiency of school principals is at the novice level (10-250 TOEIC scores). Teachers' academic competence of pre SIS and regular classes is relatively equal. The competence of biology and physics teachers of pre SIS in SSS is lower than those in the regular classes. The use of budget and finance is not transparent. Recommendation, it is important to improve teachers' academic qualification and their competence and a rigid financial and budgeting management guide.
\end{abstract}

Key words: international standard school, recruitment, academic achievement, finance, budgetting, and management.

\section{Pendahuluan}

Pemerintah telah mengembangkan dan menyelenggarakan program pendidikan yang bermutu karena berbagai alasan, antara lain: 1) untuk menciptakan sumber daya manusia unggul dan mampu bersaing dengan negara-negara lain dalam menghadapi era globalisasi; 2) sebagai benchmarking pendidikan dan mengakomodasi tuntutan masyarakat terhadap mutu pendidikan yang kompetitif; 3) banyak orang tua yang mampu secara ekonomi memilih menyekolahkan anaknya ke luar negeri sehingga menghabiskan biaya besar; dan 4) banyak sekolah yang didirikan oleh beberapa yayasan pendidikan yang menggunakan identitas internasional tetapi tidak jelas standar dan kualitasnya. Berikut adalah gambar mengenai komponen penyelenggaraan RSBI/SBI dan peraturan yang melandasinya.

Berdasarkan beberapa aspek dan peraturan terkait dalam penyelenggaraan program rintisan sekolah bertaraf internasional (RSBI) dan sekolah bertaraf internasional (SBI) di atas, maka masalah 


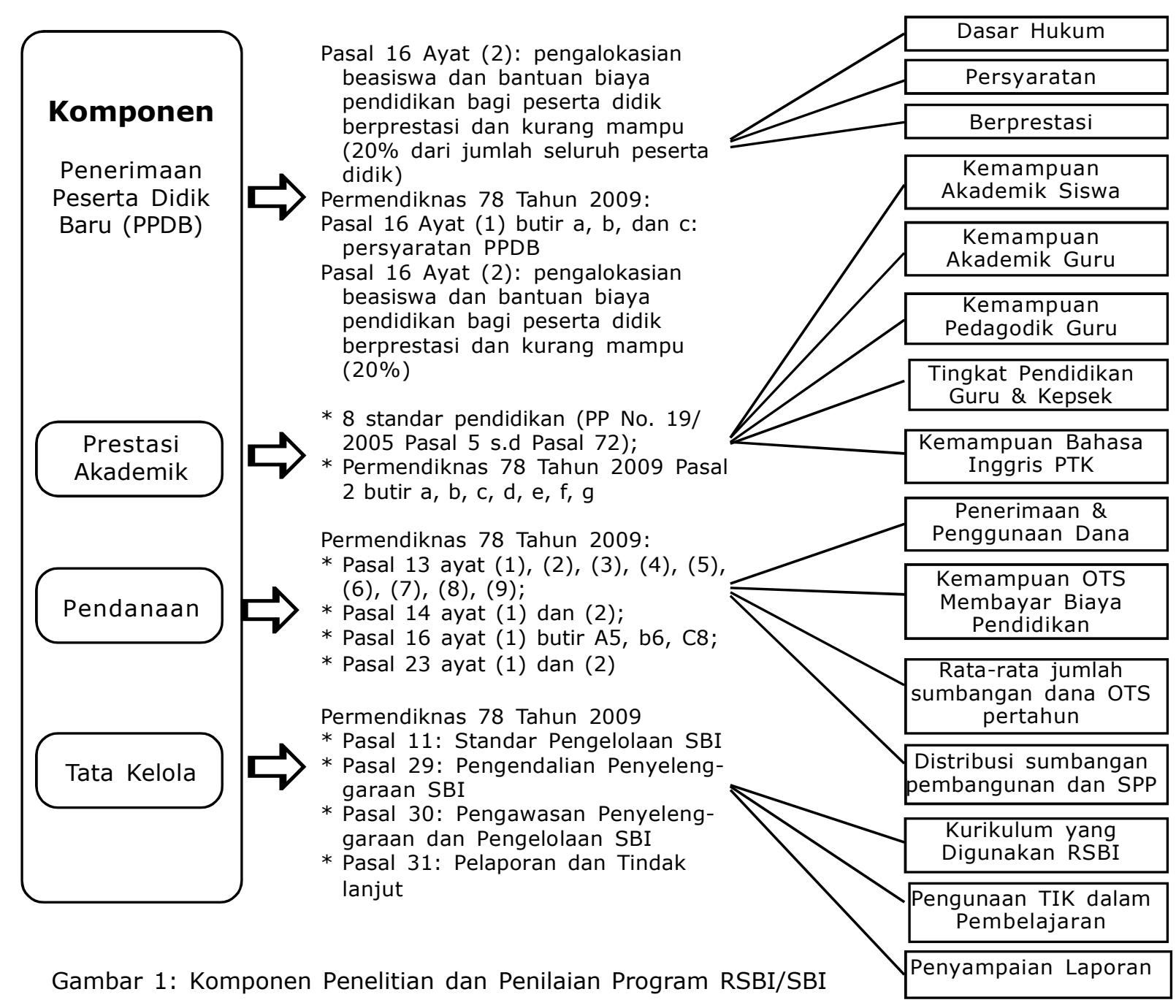

penelitian ini adalah sejak dilaksanakan pada tahun 2006 penyelenggaraan RSBI belum pernah dievaluasi secara komprehensif terutama mengenai pembiayaan yang dianggap membebani masyarakat dan pengelolaanya belum transparan. Oleh karena itu, perlu dievaluasi mengenai: 1) sistem seleksi penerimaan peserta didik baru (PPDB); 2) prestasi akademik; 3) pengelolaan pendanaan; dan 4) sistem tata kelola dan akuntabilitas penyelenggaraan RSBI/SBI di sekolah dasar (SD), sekolah menengan pertama (SMP), sekolah menengah atas (SMA), dan sekolah menengah kejuruan (SMK).

Tujuan penelitian ini adalah untuk memperoleh data dan informasi mengenai: 1) sistem seleksi penerimaan peserta didik baru (PPDB); 2) prestasi; 3) pengelolaan pendanaan; dan 4) sistem tata kelola dan akuntabilitas penyelenggaraan RSBI/SBI.

\section{Kajian Literatur}

\section{Pengertian dan Tujuan RSBI/SBI}

Sekolah bertaraf internasional (SBI) adalah sekolah yang sudah memenuhi standar nasional pendidikan (SNP) yang diperkaya dengan keunggulan mutu tertentu yang berasal dari negara anggota the Organisation for Economic Cooperation and Development (OECD) atau negara maju lainnya (Peraturan Menteri Pendidikan Nasional Nomor 78 Tahun 2009 tentang penyelenggaraan sekolah bertaraf internasional pada jenjang pendidikan dasar dan menengah).

Tujuan penyelenggaran SBI yang tertuang dalam Permendiknas No.78/2009 yaitu untuk menghasilkan lulusan yang memiliki: a) Kompetensi sesuai dengan standar lulusan dan diperkaya dengan standar kompetensi pada salah satu sekolah terakreditasi di negara anggota $O E C D$ atau negara maju lainnya; b) Daya saing komparatif tinggi yang dibuktikan dengan kemampuan 
menampilkan keunggulan lokal di tingkat internasional; c) Kemampuan bersaing dalam berbagai lomba internasional yang dibuktikan dengan perolehan medali emas, perak, perunggu, dan bentuk penghargaan internasional lainnya; d) Kemampuan bersaing ke luar negeri terutama bagi lulusan sekolah menengah kejuruan; e) Kemampuan berbahasa Inggris (skor TOEFL $>7,5$ (Permendiknas No.78/Tahun 2009) dalam skala internet based test) dan/atau bahasa asing lainnya; f) Kemampuan berperan aktif secara internasional dalam menjaga kelangsungan hidup dan perkembangan dunia dari perspektif ekonomi, sosio-kultural, dan lingkungan hidup; dan g) Kemampuan menggunakan dan mengembangkan teknologi komunikasi dan informasi secara internasional.

\section{Standar Pendidikan}

Penyelenggaraan RSBI/SBI harus memenuhi standar pendidikan, yaitu: 1) standar isi dan harus diperkaya dengan standar pendidikan dari negara anggota $O E C D$ atau negara yang pendidikanya maju; 2) proses pembelajaran mencakup perencanaan, pelaksanaan, penilaian, dan pengawasan; 3) kepala sekolah harus berpendidikan S2/S3 dan guru minimal 20\% berpendidikan S2/S3 dan mampu mengampu pembelajaran menggunakan bahasa pengantar bahasa Inggris; 4) sarana dan prasarana harus memenuhi standar sarana dan prasarana yang diperkaya dengan standar sarana dan prasarana pendidikan dari negara anggota $O E C D$ atau negara maju lainnya; 5) pengelolaan harus sesuai dengan undangundang sistem pendidikan nasional (USPN) nomor 20/2003 dan Peraturan Pemerintah Nomor 19 Tahun 2005 dan memenuhi standar pengelolaan yang diperkaya dengan standar pengelolaan sekolah di negara anggota OECD atau negara maju lainnya; dan 6) pembiayaan harus memenuhi standar pembiayaan yang memadai berdasarkan kebutuhan pencapaian ketuntasan kompetensi yang tertuang dalam kurikulum.

\section{Evaluasi Pendidikan}

Evaluasi pendidikan merupakan salah satu kegiatan yang dilakukan untuk mengetahui perkembangan pelaksanaan dan mengukur ketecapaian program pendidikan. Evaluasi juga merupakan kegiatan untuk menentukan keberhasilan program belajar siswa. Penilaian merupakan rangkaian kegiatan untuk memperoleh, menganalisis, dan menafsirkan data tentang proses dan hasil belajar peserta didik yang dilakukan melalui pengukuran secara kuantitatif atau kualitatif. Penilaian dilakukan untuk mengendalikan mutu pendidikan sebagai bentuk akuntabilitas kinerja pendidikan kepada pihakpihak yang berkepentingan. Pencapaian indikator kinerja kunci tambahan, yaitu memperkaya penilaian kinerja pendidikan dengan model penilaian sekolah unggul dari negara anggota OECD dan/atau negara maju lainnya yang mempunyai keunggulan tertentu dalam bidang pendidikan.

Rossi dan Freeman (1985:61) mendefinisikan penelitian evaluasi adalah "an integral part of broader sets of activities usually described as rational policy making, scientific decision-making, or program planning and implementation". Dalam penelitian evaluasi, semua kegiatan yang dilakukan oleh pelaksana program yang berkaitan dengan kebijakan, keputusan, perencanaan, dan pelaksanaan program harus dikaji, dinalisis, dan dinilai. Kajian tersebut dimaksudkan untuk menentukan keberhasilan program sesuai dengan rencana dan tujuan yang diinginkan. Kajian juga bertujuan untuk mengetahui kendala dan cara mengatasi kendala yang dihadapi oleh pelaksana program tersebut. Selanjutnya Sallis (2006:238) mengatakan bahwa fungsi evaluasi sering dilihat sebagai sebuah upaya pencegahan. Tujuannya adalah untuk menemukan apa yang benar dan apa yang salah dalam pelaksanaan sebuah program.

Hasil penilaian dan evaluasi akan digunakan sebagai dasar dalam menetapkan keputusan, perbaikan proses belajar mengajar, peningkatan program penyelenggaraan pendidikan, dan peningkatkan kinerja pelaksana pendidikan pada masa yang akan datang.

Selanjutnya, evaluasi kegiatan pembelajaran dilakukan untuk mengetahui pencapaian hasil belajar siswa atau kompetensi pembelajaran yang telah diajarkan pada siswa dalam batas tertentu, misalnya: evaluasi formatif untuk mengetahui pemahaman siswa mengenai satu atau dua kompetensi yang telah diajarkan pada siswa dan evaluasi sumatif dimaksudkan untuk mengetahui 
pemahaman siswa mengenai beberapa topik atau kompetensi dalam satu batas kegiatan tertentu. Evaluasi juga dapat dilakukan pada setiap akhir semester atau pada akhir kegiatan secara keseluruhan dari suatu program seperti ujian akhir sekolah (UAS) atau ujian akhir nasional (UN). Dengan demikian dapat disimpulkan bahwa evaluasi dilakukan untuk mengetahu keberhasilan pelaksanaan program yang telah direncanakan dan sebagai umpan balik dalam perbaikan program tersebut.

Dalam kaitan dengan evaluasi pelaksanaan RSBI, aspek yang dievaluasi adalah seleksi penerimaan siswa baru, pencapaian prestasi, pembiayaan, dan tata kelola.

\section{Seleksi Penerimaan Siswa Baru (PPDB)}

Kalau ingin mengetahui kemampuan awal siswa dalam kegiatan pembelajaran, maka pada umumnya guru atau sekolah melaksanakan seleksi penerimaan siswa. Dalam menentukan tingkat pemahaman siswa mengenai suatu topik, guru bisanya melakukan tes yang disebut dengan pretest. Dalam menentukan siswa yang akan ditempatkan pada tingkat (level tertentu), guru memberi tes pada siswa yang disebut dengan tes penempatan atau penentuan tingkat (placement test). Pada PPDB di RSBI, ada beberapa syarat yang harus dipenuhi oleh calon siswa. Komponenkomponen yang ditentukan sebagai syarat dalam penerimaan siswa pada setiap jenjang pendidikan berbeda-beda, misalnya: pada jenjang SD syarat sebagai calon siswa berbeda dengan syarat yang ditetapkan pada jenjang SMP atau SMA dan SMK. Hal ini berdasarkan pada ketentuan dan prediksi keberhasilan siswa dalam program yang telah ditetapkan pada level yang ingin dimasuki oleh calon siswa.

\section{Prestasi Akademik (Academic Achievement)}

Prestasi akademik adalah suatu prestasi yang ditunjukkan oleh siswa terhadap materi dan kompetensi yang dicapai berdasarkan hasil tes atau evaluasi yang telah dilakukan terhadap siswa tersebut. Dalam tes tersebut, materi tes yang diberikan pada siswa adalah materi atau kompetensi yang telah diajarkan oleh guru atau kompetensi yang telah ditetapkan untuk dikuasai oleh siswa pada tingkat/kelas dalam jangka waktu tertentu. Tes tidak diberikan pada siswa yang tidak ditentukan untuk menguasai kompetensi tertentu. Misalnya, tes untuk kelas tiga tidak diberikan pada siswa kelas dua atau sebaliknya. Hal ini dimaksudkan untuk mengetahui secara komprehensif mengenai pemahaman dan penguasaan siswa terhadap kompetensi mengenai topik tertentu. Riccards (http://the apple.monster.com/benefits/ articles) mengatakan "in today's education reform era, student achievement is king. We want to see our kids succeeding. We want to see test scores rise. We want to know we can better compete against foreign nations on things like PISA and TIMSS. We want assurances our students are getting a top-not education measure by results, and not by processes".

Dari pernyataan tersebut dapat dikatakan bahwa tes merupakan alat ukur yang tepat untuk mengetahui ketercapaian kompetensi siswa. Melalui tes, guru dapat mengetahui sejauh mana pokok bahasan atau kompetensi yang diajarkan dapat dikuasai oleh siswa. Selanjutnya, Riccards (http://the apple.monster.com/benefits/articles) mengatakan"student achievement should be our primary focus, and that we must ensure that all students are performing at the necessary levels in all subjects". Tes sebagai salah satu benchmark dan ukuran keberhasilan kegiatan pembelajaran harus mampu mengukur apa yang telah diajarkan kepada siswa, dan bukan apa yang seharusnya diketahui oleh siswa. Hal ini penting karena prinsip tes khususnya tes pencapaian akademik merupakan ukuran yang dapat menentukan keberhasilan siswa. Dengan demikian, tes yang diberikan kepada siswa sebaiknya tes yang dapat mengukur keberhasilan siswa mengenai apa yang telah dipelajarinya dan bukan untuk mengetahui kemampuan siswa secara umum apalagi untuk menguji siswa mengenai sesuatu yang belum pernah dipelajarinya.

Selanjutnya, tes juga diberikan pada guru untuk mengetahui keberhasilan mengajar yang telah dilakukan oleh mereka, seperti yang dikatakan oleh Javier (http://www.azcentral.com/ news/articles 12/10/2010) "evaluating teachers is to offers more feedback and eventually will gauge their success and salary increases, in part, on student performance and a better way of grading teachers as a current methods to sort the good 
from the bad teachers. Ukuran keberhasilan guru dalam mengajar bukan hanya kemampuan guru menguasai kompetensi atau bidang studi yang diajarkan, seperti: kompetensi pedagogik, kepribadian, profesional, dan sosial, tapi lebih dari itu yaitu untuk mengetahui sejauh mana penampilan kemampuan dan guru dalam mengajarkan ilmu kepada siswanya. Guru yang berhasil adalah guru yang dapat membawa siswanya dari tidak tahu menjadi tahu, dari tidak mengerti menjadi mengerti, dari tidak baik menjadi baik, dan sebagainya.

\section{Pembiayaan}

Untuk kelancaran pembiayaan pendidikan, maka pemerintah mengeluarkan surat keputusan (SK) bersama antara Menteri Pendidikan dan Kebudayaan, Menteri Dalam Negeri, dan Menteri Keuangan yang dituangkan dalam surat keputusan bersama (SKB) No. 0209a/K/1984 dan No. 379a/KMK0011/1984 yaitu tentang pedoman pelaksanaan subsidi/bantuan untuk komponen pengeluaran (pelaksanaan pelayanan sekolah, tata usaha, pemeliharaan sekolah, kesejahteraan pegawai sekolah, porseni sekolah, pengadaan buku laporan pendidikan, penyelenggaraan evalusai belajar tahap akhir (EBTA) dan evalusai belajar tahap akhir nasional (EBTANAS), pengadaan surat tanda tamat belajar (STTB), supervisi, pembinaan, pengelolaan, dan pelaporan serta pendataan.

Kgeledi George Kgoroba, Menteri Pendidikan Bostwana (dalam Unesco 2001:25) percaya bahwa "cost sharing and cost recovery will facilitate the transition from education for all to quality for all". Pada sisi lain, para pengelola biaya pendidikan mulai dari tingkat pusat sampai ke daerah, masih berpikir ekonomi pribadi maupun kelompok tertentu dan belum menyentuh masyarakat khususnya mereka yang tidak beruntung, Demikian pula adanya ketidakadilan pembiayaan antara sekolah swasta dan sekolah negeri di kota-kota sampai ke desa-desa, kepincangan yang luar biasa antara biaya sekolah madrasah di bawah kementerian agama dan sekolah-sekolah negeri di bawah Kementerian Pendidikan Nasional, dan kepincangan luar biasa dan ketidakadilan antara pembiayaan sekolah yang sudah maju seperti rintisan sekolah bertaraf internasional (RSBI) dan sekolah yang betul-betul masih membutuhkan biaya besar seperti sekolah di desa-desa dan di daerah terpencil.

\section{Sistem Tata Kelola dan Akuntabilitas}

Manajemen atau pengelolaan pendidikan adalah mobilisasi segala sumber daya pendidikan untuk mencapai tujuan pendidikan yang ditetapkan (Tilaar: 1998:xii dalam Zainuddin 2008:56). Dalam pendidikan unsur manajemen (tata kelola) sangat penting karena tanpa pengelololaan yang baik, maka semua program yang telah direncanakan akan sulit diterapkan dengan baik. Akibatnya, tujuan yang hendak dicapai dalam perencanaan tidak akan dapat diterapkan dalam pelaksanaannya. Pelaksanaa program pendidikan dapat dilakukan jika perencanaan program sesuai dengan kebutuhan sekolah, adanya pelaksana program khususnya kepala sekolah, pelaksana administrasi sekolah, guru, teknisi, komite sekolah, dan unsur penentu kebijakan serta siswa, orang tua siswa, dan masyarakat. Dengan demikian, tercapainya program pendidikan khususnya program sekolah akan terlaksana dengan baik jika semua komponen tersebut bekerjasama untuk mencapai tujuan yang telah direncanakan.

Definisi mutu berikutnya dilihat dari keluaran jangka panjang (outcome), misalnya melihat mutu dari pekerjaan setelah lulus dan besarnya gaji yang diperoleh. Hal itu sejalan dengan definisi relevansi yang cenderung melihat mutu dari pekerjaan setelah lulus, terutama untuk jenjang pendidikan yang lulusannya memiliki kesempatan bekerja setelah lulus. Dalam kaitan ini, Ishikawa dan Josep M. Juran (dalam Yuniarsih, 2003) mendefinisikan mutu sebagai kepuasan pelanggan dan mutu sebagai kesesuaian dengan pengguna. Selanjutnya, Eduardo Morato dalam Saepudin (2004) mengatakan: "Quality is the function of people expressing themselves in the fullest way possible." Pendapat di atas mengandung makna bahwa mutu produk merupakan hasil perpaduan usaha dari semua komponen dan dijadikan sebagai salah satu alat ukur keberhasilan produsen dengan melihat tingkat kepuasan pelanggan dan pemangku kepentingan, baik internal maupun eksternal. 


\section{Kurikulum dan Silabus}

Kurikulum RSBI/SBI berpedoman pada kurikulum nasional dan ditambah dengan kurikulum dari negara-negara anggota OECD atau negara lain yang pendidikan lebih maju.

Para ahli pendidikan memberikan definisi yang berbedan antara kurikulum dan silabus. Salah satu dari ahli tersebut adalah Nunan (1989:114) yang mendefinisikan bahwa silabus mengacu pada pemilihan isi sedangkan kurikulum mengacu pada semua aspek mulai dari perencanaan, pelaksanaan, evaluasi, dan pengaturan program pendidikan pada umumnya Krahnke (1987:3) mengatakan bahwa silabus lebih spesifik dan lebih nyata dan hanya mengatur sebagian kegiatan yang ada dalam kurikulum, sedangkan kurikulum mengatur seluruh kegiatan dalam satu tahun. Sementara itu, Candlin (1984:32) dan juga Ur (1996:176-177) mendefinisikan bahwa silabus memuat sesuatu yang akan diajarkan oleh guru dan dipelajari oleh siswa. Lebih lanjut Ur mengatakan ada 7 (tujuh) buah karakteristik silabus, yaitu: 1) memuat daftar pokok-pokok bahasan; 2) tersusun dari aspek yang mudah ke yang sukar; 3 ) mempunyai tujuan secara eksplisit; 4) merupakan dokumen publik; 5) mempunya jadwal waktu; 6) metodologinya lebih terfokus; dan 7) ada materi ajar, dan evaluasi belajar. Jadi, secara umum dapat dikatakan bahwa apapun desainnya semua kurikulum terdiri dari empat elemen pokok, yaitu: ada tujuan, isi, metode, dan penilaian.

Berdasarkan definisi-definisi tersebut di atas, maka dapat disimpulkan bahwa cakupan kurikulum lebih luas dari pada silabus atau garis besar proram pelajaran (GBPP), dan silabus memuat halhal yang lebih khusus dari masing-masing topik (pokok bahasan) yang akan diajarkan dalam kelas.

\section{Kompetensi}

Istilah kompetensi (competence) sering disamakan dengan istilah kinerja (performance). Pengertian dasar kompetensi (competence) adalah kemampuan atau kecakapan. Kay (1997) dalam Mulyasa (2002) mengatakan bahwa kompetensi merupakan: ..." an approach to instruction that aims to teach each students the basic knowledge, skill, attitudes, and values esential to competence". Selanjutnya, Spencer Lylem dan Signe Spencer
(1983:9) mendefinisikan kompetensi sebagai suatu sifat yang mendasari pribadi yang berkaitan dengan sifat pekerjaan yang efektif. Sifat yang mendasari kompetensi tersebut merupakan bagian dari kepribadian seseorang dan dapat memprediksi tingkah laku dalam berbagai situasi atau tugas pekerjaannya. Menurut mereka ada 5 (lima) jenis karakteristik kompetensi, yaitu: motives, traits, self concept, knowledge, and skill. Kompetensi ini merupakan perpaduan dari pengetahuan, keterampilan, nilai dan sikap yang direfleksikan dalam kebiasaan berpikir dan bertindak. Selanjutnya, Lefrancois (1995:5) mengatakan bahwa kompetensi merupakan kapasitas untuk melakukan sesuatu yang dihasilkan dari proses belajar. Sementara itu, Cowell R.N. (1988:95-99) mendefinisikan kompetensi sebagai suatu keterampilan/ kemahiran yang bersifat aktif. Kompetensi dikategorikan mulai dari tingkat sederhana atau dasar sampai pada tingkat yang lebih sulit atau kompleks. Dalam proses penyusunan bahan ajar atau pengalaman belajar, ada tiga aspek kompetensi yang lazimnya diperhatikan, yaitu: 1 ) penguasan minimal kompetensi dasar; 2) praktik kompetensi dasar; dan 3) penambahan penyempurnaan atau pengembangan terhadap kompetensi atau keterampilan. Ketiga proses tersebut dapat terus berlanjut selama masih ada kesempatan untuk melakukan penyempurnaan atau pengembangan kompetensinya.

Selanjutnya, kompetensi siswa adalah kata baru dalam bahasa Indonesia yang artinya setara dengan kemampuan. Siswa yang telah memiliki kompetensi mengandung arti bahwa siswa telah memahami, memaknai, dan memanfaatkan materi pelajaran yang telah dipelajarinya. Dengan perkataan lain, ia telah mampu melakukan (psikomotorik) sesuatu berdasarkan ilmu yang telah dimilikinya, dan pada tahap selanjutnya menjadi kecakapan hidup (life skills). Jenis atau tingkat kompetensi tersebut mempunyai implikasi bagi perencanaan sumber daya manusia. Kompetensi pengetahuan dan keterampilan cenderung dapat dilihat dan nampak di permukaan serta merupakan sifat seseorang. Konsep diri, sifat pembawaan (traits), dan kompetensi motivasi itu tersembunyi, ada di dalam dan terpusat pada pribadi. Kompetensi pengetahuan dan keteram- 
pilan agak mudah dikembangkan misalnya; melalui latihan dan hal ini sangat efektif untuk mengembangkan keterampilan. Sedangkan motivasi dan pembawaan agaknya sulit untuk dikembangkan.

Apabila individu sukses mempelajari cara melakukan satu pekerjaaan yang kompleks dari sebelumnya, maka pada diri individu tersebut pasti sudah terjadi perubahan kompetensi. Perubahan kompetensi tidak akan tampak apabila tidak ada kepentingan atau kesempatan untuk melakukannya. Dengan demikian bisa diartikan bahwa kompetensi adalah berlangsung lama yang menyebabkan individu mampu melakukan kinerja tertentu.

\section{Materi Ajar}

Bahan ajar merupakan salah satu komponen utama dalam pembelajaran yang dikembangkan berdasarkan kurikulum dan silabus. Oleh karena itu, bahan ajar harus dipersiapkan dengan matang oleh guru berdasarkan kebutuhan siswa. Tomlinson (2001) memberikan beberapa prinsip pengembangan bahan ajar, yaitu memberi dampak, memberi perasaan mudah bagi siswa, mengembangkan rasa percaya diri siswa, mengarahkan dan memfasilitasi siswa menemukan sendiri, membuat siswa siap belajar topiktopik yang sedang diajarkan, menggambarkan perhatian siswa melalui gejala, memberi pengaruh positif terhadap pelajaran, memperhatikan perbedaan siswa dan jangan terlalu banyak mengontrol latihan dan menyediakan umpan balik kepada siswa.

Kadang-kadang bahan ajar dirasakan sulit oleh siswa, oleh karena itu ada beberapa kriteria yang harus diperhatikan, yaitu: siswa harus merasa senang terhadap bahan ajar tersebut, lebih mudah apabila teks dihubungkan dengan budaya siswa, konkrit, dan lebih terkini (up to date), autentik, bervariasi, menarik, menstimulasi dan mengembangkan motivasi siswa, membuat siswa mampu beajar sendiri, harus bermakna, memberikan keuntungan serta menjawab persoalan dan masalah siswa.

Jenis bahan ajar dapat berupa: bahan ajar cetakan seperti buku-buku teks dan lembaran kerja, dan bahan ajar non cetak seperti kaset, video, bahan ajar berbasis komputer seperti internet. Jenis bahan ajar di RSBI/SBI dikembang- kan dari bahan ajar yang diadopsi atau diadaptasi dari sister school-nya atau lembaga pendidikan di negara $O E C D$ atau negara maju lainnya.

\section{Model Pembelajaran di RSBI/SBI}

Model pembelajaran yang digunakan di RSBI/SBI beragam, antara lain model pembelajaran: contextual Learning ( $C T L)$, examples non examples, picture and picture, number heads together, cooperative script, kepala bernomor struktur, tim peserta didik kelompok prestasi, berdasarkan masalah, artikulasi, mind mapping, mencari pasangan, think pair and share, debate, role playing, group investigation, talking stick, bertukar pasangan, snowball throwing, student facilitator and explaining, course review horay, demonstration, pengajaran langsung, kooperatif terpadu membaca dan menulis, lingkaran kecil lingkaran besar, pembelajaran tebak kata, concept sentence, complete sentence, time token, keliling kelompok, dua tinggal dua tamu, PAKEM, PAIKEM, dan CBSA. Model pembelajaran ini semua merupakan model yang dapat dipilih dalam kegiatan pembelajaran sesuai dengan tujuan yang ingin dicapai dan konteks siswa. Dengan demikian, sebuah model pembelajaran digunakan sebagai cara untuk mencapai keberhasilan pembelajaran berdasarkan tujuan yang ingin dicapai.

\section{Metode Penelitian}

Penelitian ini menggunakan metode evaluasi. Sampel dipilih secara purposive di 16 provinsi dan masing-masing provinsi dipilih tiga SD, SMP, SMA, dan tiga SMK yang memenuhi syarat yang ditentukan antara lain sudah melaksanakan RSBI selama 3 tahun. Resonden penelitian sebanyak 4.575.910 orang yang terdiri atas 130 orang komite sekolah, 130 orang kepala sekolah, 426 guru, 4.224 orang orang tua siswa, dan 4.571 siswa.

Pengumpulan data menggunakan instrumen, wawancara, focus group discussion (FGD), tes kompetensi guru dan siswa. Selain itu, data diperoleh melalui studi dokumen yaitu data dari stakeholders, hasil studi terkait, dan perundangundangan yang terkait dengan penyelenggaraan RSBI. Berikut ringkasan jumlah sampel penelitian RSBI.

Analisis data menggunakan teknik analisis kuantitatif dan analisis kualitatif. Analisis kuanti- 
tatif untuk mengetahui persentase dan kecenderungan (trend) tentang keempat komponen yang diteliti (sistem seleksi penerimaan peserta didik baru (PPDB) (recruitment), academic achievement, pengelolaan pendanaan, dan sistem tata kelola dan akuntabilitas penyelenggaraan RSBI. Untuk mendalami temuan tersebut, data juga dianalisis secara kualitatif untuk melihat mengapa dan bagaimanan kondisi tentang komponenkomponen yang diteliti tersebut.

\section{Temuan Penelitian dan Pembahasan Persyaratan Penerimaan Peserta Didik Baru (PPDB)}

Dari komponen utama yang dipersyaratkan dalam PPDB (kemampuan akademik, IQ, nilai UN, minat dan bakat, dan kesehatan) terungkap bahwa di SD komponen utamanya adalah adalah IQ $(37,7 \%)$, SMP adalah kemampuan akademik $(22,7 \%)$, SMA adalah kemampuan akademik $(23,8 \%)$, dan SMK adalah nilai UN (23,5\%).

Permendiknas No. 78 thn 2009 Pasal 16 ayat 2 mengamanatkan bahwa SBI wajib mengalokasi- kan beasiswa atau bantuan biaya pendidikan bagi peserta didik WNI yang memiliki potensi akademik tinggi tetapi kurang mampu secara ekonomi paling sedikit $20 \%$ dari jumlah seluruh peserta didik. Jenis-jenis beasiswa, antara lain:1) miskin berprestasi; 2) alumni; 3) bantuan khusus murid (BKM); 4) beasiswa Pemda; 5) beasiswa bakat berprestasi; 6. program keahlian khusus (SMK). Berdasarkan permen tersebut, data siswa miskin yang diterima di RSBI baru mencapai 16,2\%. Namun demikian, hampir semua RSBI telah mempertimbangkan siswa miskin berprestasi untuk memperoleh akses dalam penerimaan peserta didik baru (PPDB). Persentase siswa miskin yang diterima di RSBI cenderung meningkat mulai tahun 2008 sampai tahun 2010.

\section{Prestasi Akademik}

Di SD, kempuan bahasa Inggris dan IPA siswa RSBI lebih tinggi dari siswa reguler. sedangkan kemampuan matematika siswa RSBI dan siswa regular relatif sama. Kemampuan guru kelas SD RSBI relatif lebih baik dari pada guru kelas reguler.

Tabel 1. Afirmasi Siswa Miskin

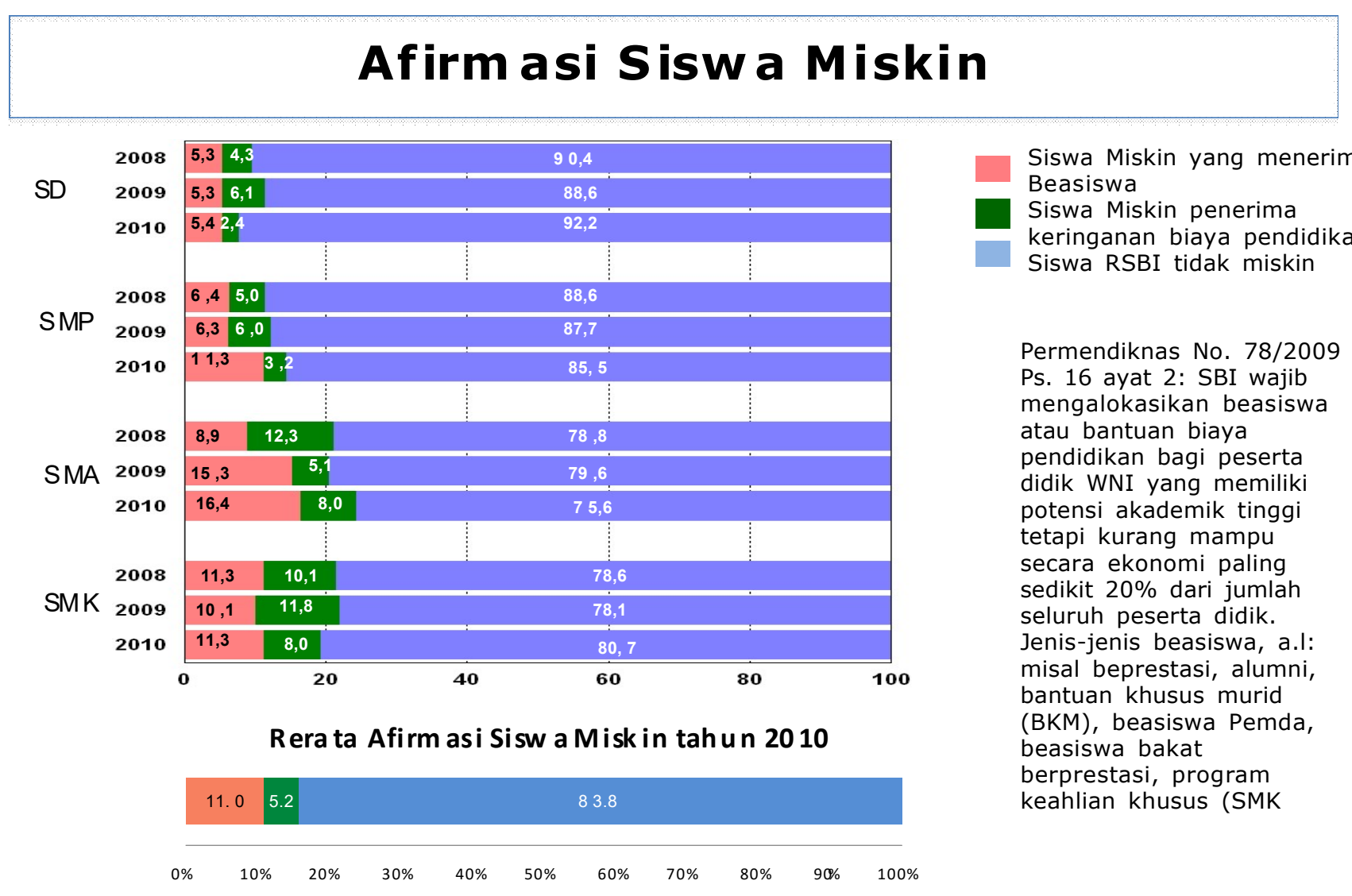


Guru kelas RSBI memberi kontribusi positif terhadap prestasi bahasa Inggris dan IPA, sedangkan untuk matematika tidak. Hal ini menunjukkan bahwa tingginya kemampuan akademik siswa didukung oleh kemampuan guru yang tinggi.

Di SMP, ditemukan bahwa kemampuan siswa dan guru kelas RSBI dalam bidang studi bahasa Inggris, Matematika, dan IPA (biologi) lebih tinggi dari kemampuan siswa dan guru kelas reguler. Namun, kemampuan guru IPA (Fisika) kelas RSBI dan guru IPA (Fisika) kelas reguler relatif sama. Walaupun kemampuan guru sama, tetapi siswa RSBI memiliki kemampuan yang lebih tinggi dari pada siswa kelas. Hal ini berarti tingginya kemampuan akademik siswa didukung oleh kemampuan guru yang tinggi.

Di SMA, kemampuan bahasa Inggris siswa RSBI lebih tinggi daripada siswa reguler, sedangkan kemampuan guru bahasa Inggris kelas RSBI dan kelas reguler relatif sama. Kemampuan matematika dan IPA siswa RSBI SMA lebih tinggi daripada siswa kelas reguler. Sebaliknya, kemampuan guru Biologi dan Fisika kelas RSBI di
SMA lebih rendah daripada kemampuan guru biologi guru kelas reguler. Rendahnya kemampuan guru biologi dan IPA tidak terkait langsung dengan prestasi akademik siswa.

Di SMK, kemampuan bahasa Inggris dan matematika siswa RSBI lebih tinggi daripada siswa kelas reguler.

Kemampuan pedagogik guru SD di kelas reguler cenderung lebih baik daripada guru kelas RSBI. Sebaliknya, di tingkat SMP dan SMA kemampuan pedagogik guru RSBI cenderung lebih baik dibanding dengan guru sekolah reguler.

Kemampuan bahasa Inggris pendidik dan tenaga kependidikan di RSBI sebagian besar masih pada level novice (skor 10-250) yaitu sekitar $50 \%$. Hanya $12,9 \%$ guru yang mencapai level intermediate dan hanya $0,1 \%$ yang mampu mencapai profesional proficiency. Ini menunjukkan bahwa guru belum mampu berbahasa Inggris dan belum mencapai ketentuan untuk mengajar menggunakan bahasa Inggris di kelas RSBI.

Kemampuan bahasa Inggris kepala sekolah RSBI masih kurang. Sebagian besar $(51,0 \%)$

Grafik 1. Kemampuan Guru Bahasa Inggris, Guru Matematika, dan Sains

Kemampuan Bahasa Inggris

Guru Matematika dan Sains RSBI Tah un 2008

(men ggu nakan Test of English International Communication --TOEIC)

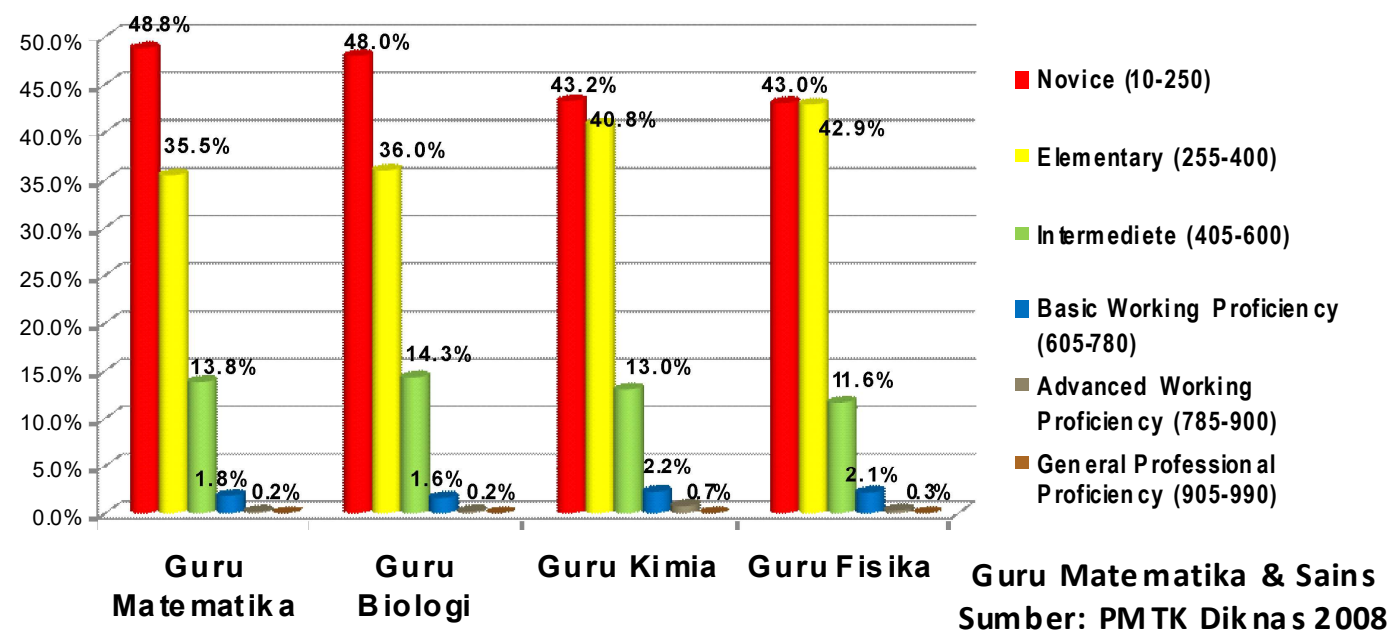

Kemampuan bahasa Inggris guru matematika dan sains RSBI pada awal setahun penetapan RSBI (tahun 2007) sebagian besar (43\%-48,8\%) masih berada pada level novice dan sebanyak 35,5\%$42,9 \%$ baru mencapai level elementary. Selama dua tahun terakhir telah mengikuti pelatihan untuk meningkatkan kemmapuan bahasa Inggrisnya. Sesuai dangan Permen 78 tahun 2009 tentang Sistem penyelenggaraan SBI pada jenjang pendidikan Dasar dan Menengah Pasal 5 ayat 3: RSBI/SBI dapat menggunakan bahasa pengantar bahasa Inggris dan/atau bahasa asing lainnya yang digunakan dalam forum internasional sebagai bahasa pengantar dalam mengajarkan mata pelajaran tertentu (misalnya: guru Matematika dan Sains dituntut dapat mengampu bidang studinya dalam bahasa Inggris. 
kepala sekolah, bahasa Inggrisnya masih berada pada level novice (skor 10-250), sedangkan persyaratan untuk menjadi kepala sekolah SBI adalah mereka yang mampu menggunakan bahasa Inggris secara aktif atau mereka yang sudah mencapai skor TOEIC minimal 405-600 (level intermediate). Kepala Sekolah yang memenuhi persyaratan baru mencapai $14.6 \%$.

Sebagian besar guru bahasa Inggris RSBI $(39,4 \%)$ telah memenuhi syarat kemampuan bahasa Inggris yaitu level intermediate. Sebanyak $21,7 \%$ telah mencapai level yang lebih tinggi (Basic Working Proficiency). Hanya sebagian kecil $(7,4 \%)$ yang masih kurang (level Novice dan $26,1 \%$ baru mencapai level Elementary). Berikut adalah grafik mengenai kemampuan bahasa Inggris guru matematika dan IPA.

Tingkat pendidikan kepala sekolah pada semua jenjang pendidikan belum seluruhnya memenuhi persyaratan S2 (sesuai ketentuan menjadi Kepsek). Kepala sekolah Dasar (SD) yang berkualifikasi S2 belum sampai 50\%, sedangkan kepala sekolah SMP, SMA/SMK sudah di atas 50\% berkualifikasi S2.

Tingkat pendidikan guru di semua satuan pendidikan bervariasi. Tingkat pendidikan guru SD baru mencapai 10,9\%, guru SMP 18,3\%, guru SMA $23,4 \%$, dan guru SMK baru 15,6\%. Kalau dilihat dari persyaratan untuk menjadi guru RSBI ( $10 \%$ untuk SD, 20\% untuk SMP, dan 30\% untuk SMA/ SMK berkualifikasi pendidikan S2), maka hanya guru SD yang sudah mencapai ketentuan $10 \%$ yaitu sudah mencapai 10,9\%.

\section{Pengelolaan Pendanaan}

Penerimaan dan penggunaan dana SDN RSBI persekolah dan persiswa tahun 2009/2010 (dalam ribuan rupiah) adalah: Penerimaan dana sekolah terbesar berasal dari APBN, diikuti oleh sumbangan orangtua siswa/masyarakat, APBD Kabupaten/Kota, dan APBD Provinsi. Penggunaan dana terbesar diperuntukkan pada: 1) sarana prasarana yang meliputi pengembangan sumber belajar, perpustakaan, sarana penunjang pembelajaran, TIK; 2) pengembangan dan kesejahteraan PTK (pengembangan sumber belajar); dan 3) PBM.

Penerimaan dan penggunaan dana SMPN RSBI persekolah dan per siswa tahun 2009/2010. Penerimaan dana sekolah terbesar berasal dari sumbangan orgtua siswa/masyarakat dan digunakan untuk melengkapi sarana dan prasarana penunjang pembelajaran, pengembangan PBM, manajemen berbasis TIK dan ISO, serta pengembangan benchmarking/sister school. Anggaran lainnya berasal dari APBN, APBD Provinsi dan APBD Kabupaten/Kota. Penggunaan dana terbesar adalah untuk melengkapi dan mengem-

Grafik 2. Komponen sumbangan orang tua RSBI/SBI

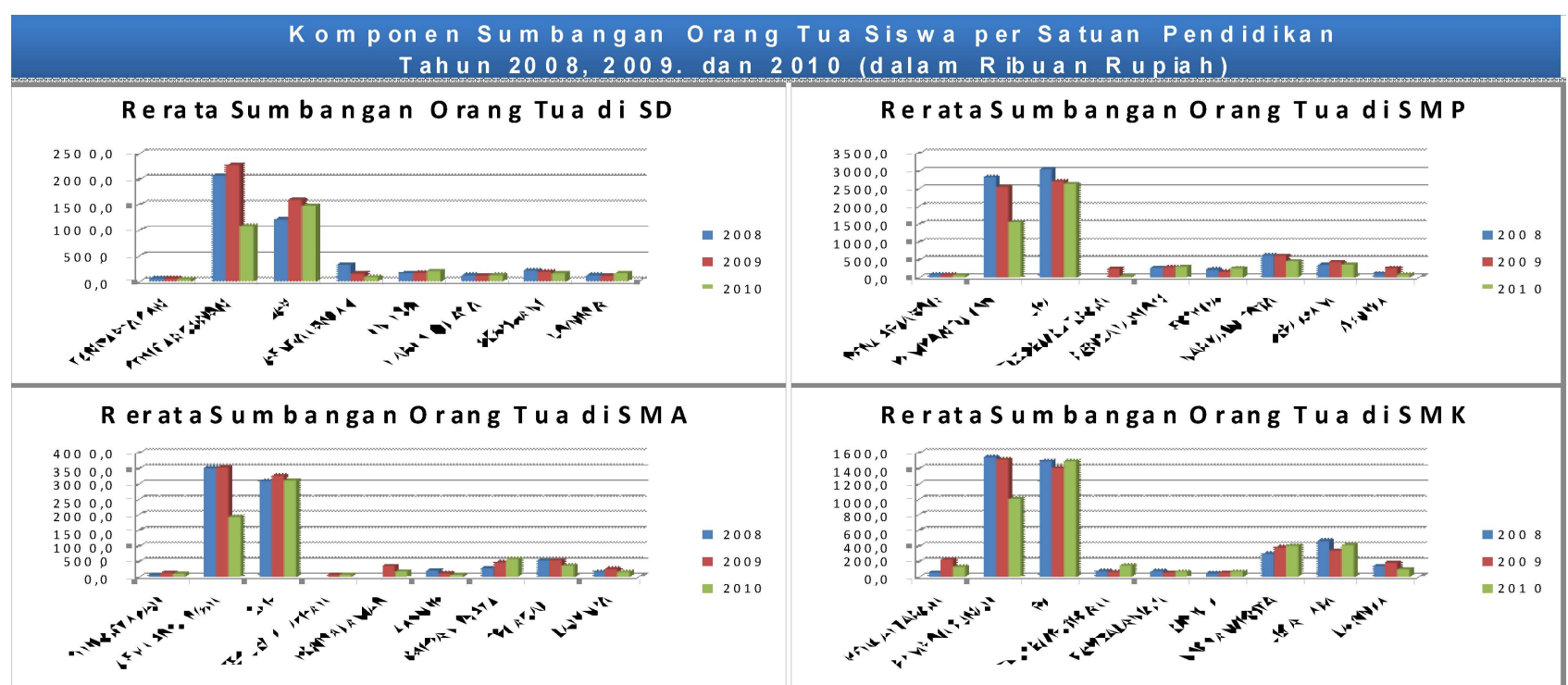

Sum bangan pembangunan dise muasatuan pendidikan cenderung m en urun selam a tiga tahun terak hir, sedangka $n$ sum bang an SPP relat if stabil. 
bangkan sarana prasarana yaitu: pengembangan sumber belajar, laboratorium, TIK, PBM, kesejahteraan, dan pengembangan PTK.

Penerimaan dan penggunaan dana SMAN persekolah dan persiswa tahun 2009/2010. Penerimaan dana sekolah terbesar berasal dari sumbangan orgtua siswa/masyarakat diikuti oleh APBN, APBD provinsi dan APBD kabupaten/kota. Penggunaan dana terbesar digunakan untuk pengembangan dan perbaikan sarana prasarana, kesejahteraan PTK, kegiatan siswa, dan PBM.

Penerimaan dan penggunaan dana SMKN RSBI persekolah dan per siswa tahun 2009/2010. Penerimaan dana sekolah terbesar berasal dari sumbangan orang tua siswa/masyarakat diikuti oleh APBN, APBD provinsi, dan APBD kabupaten/ kota. Penggunaan dana terbesar diperuntukkan pada sarana prasarana (bengkel/workshop) diikuti oleh pengembangan dan kesejahteraan PTK, misalnya: untuk pengembangan profesional guru seperti pengembangan materi ajar dan metode pembelajaran dan PBM.

Grafik di atas menunjukkan pungutan terhadap orang tua yang relatif tinggi terjadi pada tahun 2008 dan 2009. Pada tahun 2010, sumbangan orang tua cenderung menurun dibandingkan dua tahun sebelumnya. Grafik di atas juga menunjukkan bahwa SD dan SMK umumnya memungut biaya yang lebih rendah dibandingkan SMA dan SMP.

Persepsi orang tua tentang kemampuan membayar biaya pendidikan di RSBI/SBI terungkap bahwa hampir semua orangtua siswa berpendapat beban biaya pendidikan di RSBI tidak berat. Sekitar $28,95 \%$ orang tua siswa RSBI berpendapat bahwa tingkat kemampuan membayar pendidikan adalah ringan, dan sekitar $61,66 \%$ berpendapat sedang dan hanya 9,39\% berpendapat berat.

Distribusi sumbangan pembangunan dan SPP di SDN tahun 2009/2010 ditemukan bahwa sumbangan pembangunan di SDN berkisar antara Rp. 100 ribu hingga maksimum 7,7 juta dengan rata-rata Rp. 1,5 juta. Sedangkan SPP bulanan di SDN berkisar antara Rp. 20 ribu hingga Rp. 505 ribu dengan rata-rata Rp. 145 ribu. Sumbangan pembangunan lebih kecil dari 4 juta berada 96\%, sedangkan SPP lebih kecil dari 300 ribu berada $96 \%$.
Distribusi sumbangan pembangunan dan SPP di SMPN tahun 2009/2010 ditemukan bahwa sumbangan pembangunan di SMPN berkisar antara Rp. 250 ribu hingga maksimum Rp. 15 juta dengan rata-rata Rp 2,23 juta. Sedangkan SPP bulanan di SMPN berkisar antara Rp 25 ribu hingga Rp 556 ribu dengan rata-rata Rp 230 ribu. Sumbangan pembangunan lebih kecil dari 5 juta sebanyak $90 \%$, sedangkan SPP lebih kecil 500 ribu sebesar $97,5 \%$.

Distribusi sumbangan pembangunan dan SPP di SMAN tahun 2009/2010 terungkap bahwa sumbangan pembangunan di SMAN berkisar antara Rp 135 ribu hingga maksimum Rp 10 juta dengan rata-rata Rp 2,7 juta. Sedangkan SPP bulanan di SMA berkisar antara Rp 100 ribu hingga Rp 450 ribu dengan rata-rata Rp 265 ribu. Sumbangan pembangunan lebih kecil dari 5 juta sebesar $88 \%$, sedangkan SPP lebih kecil dari 300 ribu sebesar $84 \%$.

Distribusi sumbangan pembangunan dan SPP di SMK tahun 2009/2010 ditemukan bahwa sumbangan pembangunan di SMK berkisar antara Rp. 125 ribu hingga maksimum Rp 3,8 juta dengan rata-rata Rp 1,28 juta. Sedangkan SPP bulanan di SMK berkisar antara Rp 56 ribu hingga Rp 320 ribu dengan rata-rata Rp 128 ribu. Sumbangan pembangunan lebih kecil dari 2 juta sebanyak $77 \%$, sedangkan SPP lebih kecil dari 200 ribu sebesar $90 \%$.

\section{Sistem Tata Kelola dan Akuntabilitas}

Kurikulum yang digunakan. Kurikulum yang digunakandi oleh semua satuan pendidikan RSBI/ SBI adalah KTSP

Belum semua sekolah RSBI menggunakan KTSP yang diperkaya dengan kurikulum negara anggota OECD atau negara yang pendidikannya lebih maju. Sebagian besar satuan pendidikan RSBI masih menggunakan KTSP. Hal ini menunjukkan bahwa sebagian sekolah belum mampu mengakomodasi tuntutan pengelolalaan sekolah khususnya pengayaan KTSP dengan kurikulum negara yang pendidikannya maju. Kalau pengelolaan sekolah tidak terencana dengan baik, seperti yang dikemukakan oleh Tilaar (1998:xii dalam Zainuddin 2008:56) bahwa unsur manajemen (tata kelola) sangat penting karena tanpa pengelololaan yang baik, maka semua 


\section{KURIKULUM YANG DIGUNAKANRSBI}

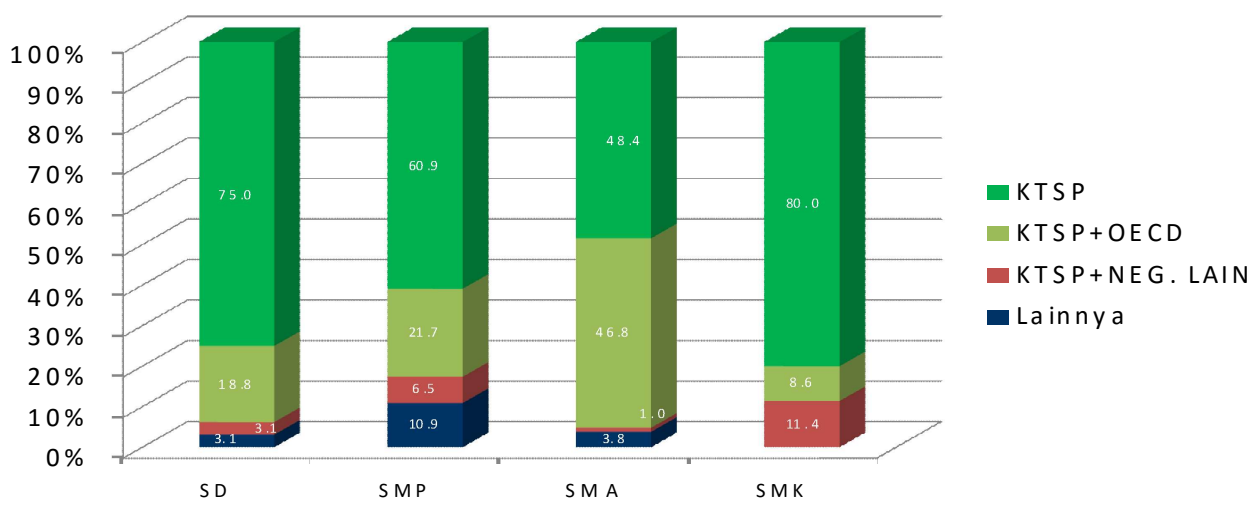

Belum semua sekolah RSBI menggunakan KTSP yang diperkaya dengan kurikulum negara anggota OECD atau negara maju lainnya. Sebagian besar satuan pendidikan RSBI masih menggunakan KTSP

program yang telah direncanakan akan sulit diterapkan dengan baik. Ini terlihat bahwa sebagaian besar sekolah belum menerapkan pengelolaan kurikulum seperti yang ditetapkan dalam Permendiknas No.78/Tahun 2009.

Tingkat kepuasan orang tua terhadap layanan RSBI/SBI berdasarkan komponen layanan di SD, SMP, SMA, dan SMK adalah: sekitar 19,8\% orangtua siswa RSBI berpendapat bahwa tingkat pelayanan penyelenggaraan RSBI sangat memuaskan, dan sekitar $72,6 \%$ berpendapat memuaskan. Hanya sebagian kecil orang tua siswa, yakni 7,6\%, yang tidak puas dengan layanan RSBI. Berikut adalah tabel penyampaian laporan penyelenggaraan RSBI ke Stakeholders dalam kurun waktu tertentu (laporan bulanan, laporan semesteran, dan laporan tahunan).

Tabel 2: Penyampaian Laporan

\begin{tabular}{|c|c|c|c|c|}
\hline \multicolumn{5}{|c|}{ Penyampaian Laporan Bulanan, Semesteran, dan Tahunan } \\
\hline & SD & SMP & SMA & SMK \\
\hline Bulanan & $\begin{array}{l}\text { Laporan } \\
\text { bulanan paling } \\
\text { sering } \\
\text { disampaikan } \\
\text { kepada Komite } \\
\text { Sekolah } \\
\end{array}$ & $\begin{array}{l}\text { Laporan } \\
\text { bulanan paling } \\
\text { sering disam- } \\
\text { paikan kepada } \\
\text { Komite Sekolah }\end{array}$ & $\begin{array}{l}\text { Laporan bulanan } \\
\text { paling sering } \\
\text { disampaikan } \\
\text { kepada Komite } \\
\text { Sekolah }\end{array}$ & $\begin{array}{l}\text { Laporan bulanan } \\
\text { paling sering } \\
\text { disampaikan } \\
\text { kepada Komite } \\
\text { Sekolah }\end{array}$ \\
\hline $\begin{array}{l}\text { Semester- } \\
\text { an }\end{array}$ & $\begin{array}{l}\text { Laporan } \\
\text { semesteran } \\
\text { paling sering } \\
\text { disampaikan } \\
\text { kepada Komite } \\
\text { Sekolah }\end{array}$ & $\begin{array}{l}\text { Laporan } \\
\text { semesteran } \\
\text { paling sering } \\
\text { disampaikan } \\
\text { kepada Dinas } \\
\text { Kabupaten/Kota }\end{array}$ & $\begin{array}{l}\text { Laporan semes- } \\
\text { teran paling } \\
\text { sering disampai- } \\
\text { kan kepada Dinas } \\
\text { Kabupaten/Kota }\end{array}$ & $\begin{array}{l}\text { Laporan semes- } \\
\text { teran paling sering } \\
\text { disampaikan } \\
\text { kepada Dinas } \\
\text { Kabupaten/Kota }\end{array}$ \\
\hline Tahunan & $\begin{array}{l}\text { Laporan } \\
\text { Tahunan paling } \\
\text { sering disam- } \\
\text { paikan kepada } \\
\text { orang tua, } \\
\text { Dinas Kab/ } \\
\text { Kota, dan Ditjen } \\
\text { Mandikdasmen } \\
\end{array}$ & $\begin{array}{l}\text { Laporan } \\
\text { Tahunan paling } \\
\text { sering disam- } \\
\text { paikan kepada } \\
\text { Dinas Provinsi } \\
\text { dan Ditjen } \\
\text { Mandikdasmen }\end{array}$ & $\begin{array}{l}\text { Laporan Tahunan } \\
\text { paling sering } \\
\text { disampaikan } \\
\text { kepada Dinas } \\
\text { Kabupaten/Kota, } \\
\text { Dinas Provinsi } \\
\text { dan Ditjen } \\
\text { Mandikdasmen }\end{array}$ & $\begin{array}{l}\text { Laporan Tahunan } \\
\text { paling sering } \\
\text { disampaikan } \\
\text { kepada Dinas } \\
\text { Kabupaten/Kota, } \\
\text { Dinas Provinsi, dan } \\
\text { Ditjen } \\
\text { Mandikdasmen }\end{array}$ \\
\hline
\end{tabular}




\section{Simpulan dan Saran Simpulan}

Berdasarkan temuan penelitian dapat disimpulkan, sebagai berikut:

Penerimaan Peserta Didik Baru (PPDB): Berdasarkan temuan penelitian yang diuraikan di atas, maka dalam PPDB dapat disimpulkan, sebagai berikut: 1) Dalam penyelenggaraan PPDB semua RSBI telah mengacu kepada dasar hukum dan ketentuan yang ditetapkan. Di tingkat SD yang paling dipertimbangkan adalah hasil tes kecerdasan/IQ, di tingkat SMP dan SMA yang digunakan adalah kemampuan akademik dan tes minat dan bakat, sedangkan di SMK yang digunakan adalah hasil tes kesehatan dan nilai UN dan 2) RSBI memberikan afirmasi bagi siswa kurang mampu. Siswa dari keluarga kurang mampu tetapi berprestasi telah mendapat kesempatan untuk belajar di RSBI. Sebagian besar siswa yang tidak mampu tersebut telah memperoleh beasiswa.

Prestasi Akademik: Siswa RSBI menunjukkan prestasi akademik yang lebih baik daripada siswa reguler, yaitu: 1) Nilai akademik siswa SD RSBI untuk mata pelajaran matematika, bahasa Inggris, dan IPA rata-rata lebih tinggi $12 \%$ dari siswa reguler; 2) Nilai akademik siswa SMP RSBI untuk mata pelajaran matematika, bahasa Inggris, dan IPA rata-rata lebih tinggi $15,5 \%$ dari siswa reguler; 3) Nilai akademik siswa SMA RSBI untuk mata pelajaran matematika, bahasa Inggris, dan IPA rata-rata lebih tinggi 19,5\% dari siswa reguler; 4) Nilai akademik siswa SMK RSBI untuk mata pelajaran matematika dan bahasa Inggris rata-rata lebih tinggi $20,4 \%$ dari siswa reguler; 5)Belum semua kepala sekolah memenuhi persyaratan kualifikasi akademik (S2). (Tambah data). Sebagian besar guru RSBI belum memenuhi kriteria kualifikasi pendidikan S2 (SMP $=18,3 \%$; SMA $=23,4 \%$; SMK $=15,6 \%)$, kecuali SD $(10,9 \%)$. Persyaratan guru RSBI, yaitu 10\% untuk SD, 20\% untuk SMP, dan 30\% untuk SMA/SMK berkualifikasi pendidikan S2; dan 6) Kemampuan Bahasa Inggris Pendidik dan Tenaga Kependidikan RSBI pada SD, SMP, SMA, dan SMK masih pada level novice (skor 10-250) yaitu sekitar $50 \%$.

Pengelolaan Pendanaan: Sumber dana untuk penyelenggaraan pendidikan RSBI di SD (70\%) dan SMP (56\%) terbesar berasal dari APBN,
APBD Provinsi, dan APBD Kabupaten/Kota. Sedangkan sumber dana untuk penyelenggaraan pendidikan RSBI di untuk penyelenggaraan pendidikan RSBI SMA (78\%) dan SMK (64\%) terbesar berasal dari sumbangan orang tua dan masyarakat. Ini menunjukkan bahwa RSBI menyalahi ketentuan pasal 13 bagian ke tujuh Permendiknas No.78 tahun 2009 yang berbunyi "SBI dapat memungut biaya pendidikan untuk menutupi kekurangan biaya di atas standar pembiayaan yang didasarkan pada RPS/RKS dan RKAS". Hal ini menunjukkan bahwa pungutan biaya dari masyarakat jauh lebih besar dari dana yang diterima dari anggaran pemerintah. Sebagian besar penggunaan dana dimanfaatkan untuk sarana dan prasarana yaitu mulai dari $38-47 \%$ diikuti oleh kesejahteraan dan pengembangan PTK yang berkisar antara 15\%-20\%, PBM yang berkisar antara 9\%-18\%, kegiatan siswa yang berkisar antara 4\%-10\%, dan manajemen sekolah dan manajemen komite yang berkisar antara $8 \%$ $18 \%$.

Tata Kelola dan Akuntabilitas: RSBI yang menggunakan KTSP dan diperkaya dengan kurikulum negara anggota OECD atau negara yang pendidikanya lebih maju yaitu SD $(21,9 \%)$, SMP $(28,2 \%)$, SMA $(46,76 \%)$, dan SMK (20\%). TIK di RSBI telah digunakan untuk perencanaan, pelaksanaan, dan penilaian pembelajaran; dan 3) Secara umum, RSBI telah mengirimkan laporan bulanan, semesteran, dan tahunan kepada komite sekolah, Dinas Kabupaten/Kota, Dinas Provinsi, dan Ditjen Mandikdasmen.

\section{Saran}

Berdasarkan simpulan tersebut di atas, berikut beberapa rekomendasi yang perlu diperhatikan, yaitu:

Penerimaan Peserta Didik Baru (PPDB): 1) Perlu ada penataan terhadap sistem penerimaan peserta didik baru (PPDB), termasuk penguatan transparansi sistem penerimaan. Dalam rekrutmen siswa baru, salah satu hal yang perlu dipertimbangkan adalah kesamaan visi sekolah dan orang tua. Hal ini mengingat bahwa pendidikan adalah proses yang utuh yang dijalankan oleh pendidik di sekolah dan orang tua di rumah. Oleh karena itu, perlu dilakukan wawancara menyangkut komitmen orang tua dan 
2) Perlu peningkatan afirmasi bagi siswa kurang mampu sesuai dengan ketentuan perundangan yang berlaku. Dalam rekrutmen siswa baru, hal penting yang perlu dipertimbangkan adalah kedekatan tempat tinggal siswa dengan lokasi sekolah. Hal ini sesuai dengan kampanye global tentang Education For All (EFA) UNESCO yang juga menjadi komitmen pemerintah.

Prestasi Akademik: 1) Untuk mempertahankan dan meningkatkan prestasi siswa, perlu peningkatan kualitas pembelajaran di sekolah dengan memaksimalkan penggunaan TIK, perlu peningkatan kualifikasi akademik dan kompetensi guru dan kepala sekolah, pemerintah, pemerintah daerah provinsi, dan kabupaten/kota perlu menyediakan sumber daya dalam rangka pencapaian kualifikasi pendidikan guru sesuai persyaratan dan 2) Perlu dilakukan pembinaan terus menerus tentang peningkatan kemampuan bahasa Inggris bagi pendidik dan tenaga kependidikan.

Pengelolaan Pendanaan: 1) Perlu ada ketentuan mengenai persentase kontribusi dana pendidikan yang bersumber dari orang tua siswa dari seluruh sumber pendanaan pendidikan RSBI dalam rangka pengendalian besarnya sumbangan/pungutan dari orang tua siswa; 2) Perlu disusun panduan tentang pengelolaan pendanaan pendidikan terkait dengan sumber dana, pemanfaatan, dan administrasi keuangan serta aspek pendanaan lainnya dalam rangka menjamin transparansi dan akuntabilitas pengelolaan anggaran RSBI di tingkat satuan pendidikan; 3) Sekolah-sekolah negeri yang dirancang sebagai satuan pendidikan yang bertaraf internasional tidak diperkenankan memungut biaya dari peserta didik/orang tua. Hal ini berpotensi mendukung berlangsungnya komersialisasi pendidikan dan menyalahi ketentuan undang-undang; 4)
Sekolah-sekolah tersebut harus sepenuhnya dibiayai oleh pemerintah dengan mendorong para pengelolanya untuk kreatif mendapatkan sumbersumber dana tambahan; 5) Prioritas alokasi dana pendidikan secara berurutan adalah: pembelajaran, pengembangan mutu pendidik, pengembangan sarana dan prasarana, dan kegiatan kesiswaan. Dana yang dialokasikan khusus sebagai pengembangan satuan pendidikan yang bertaraf internasional tersebut tidak boleh digunakan untuk menambah gaji/tunjangan; dan 6) Pengelolaan dana pendidikan yang bersumber dari pemerintah harus dilakukan oleh pihak manajemen sekolah sendiri.

Tata Kelola dan Akuntabilitas: 1) RSBI yang belum memenuhi ketentuan kurikulum perlu segera memperkaya kurikulum dengan cara adopsi atau adaptasi kurikulum negara-negara yang pendidikanya lebih maju; 2) Karena kemampuan akademik guru RSBI masih rendah untuk beberapa mata pelajaran (biologi, fisika, dan bahasa Inggris), maka perlu pemanfaatan TIK yang lebih terarah dalam pembelajaran; 3) Perlu penguatan monitoring dan evaluasi terhadap pemanfaatan hasil laporan sekolah RSBI untuk peningkatan kualitas tata kelola; 4) Perlu mekanisme rekrutmen guru yang lebih selektif sebagai bagian dari upaya meningkatkan mutu proses pembelajaran; 5) Penggunaan merek tertentu untuk melegitimasi standar mutu pengelolaan seperti ISO tidak terlalu relevan. Cukup digunakan standar proses yang ada dengan menambahkan hal-hal tertentu yang diperlukan; dan 6) Untuk mengontrol akuntabilitas pengelolaan dan mutu penyelenggaraan, sekolah wajib memberikan laporan tiap semester kepada Menteri melalui Ditjen Pendidikan Dasar dan Dirjen Pendidikan Menengah.

\section{Pustaka Acuan}

Christopher N. Candlin. 1984. Syllabus Design As A Critical Process. In General English Syllabus Design Edited by Brumfit G.J. Exeter. A Wheaton Ltd.

Departemen Pendidikan Nasional: Peraturan Menteri Pendidikan Nasional Nomor 78 Tahun 2009 tentang Penyelenggaraan Sekolah Bertaraf Internasional pada Jenjang Pendidikan Dasar dan Menengah

- - - - - Surat Keputusan Bersama antara Menteri Pendidikan dan Kebudayaan, Menteri Dalam Negeri, dan Menteri Keuangan yang dituangkan dalam SKB tanggal 2 Mei 1984 No.0209a/K/ 
1984 dan No.379a/KMK0011/1984 yaitu tentang Pedoman Pelaksanaan Subsidi/bantuan untuk komponen pengeluaran

Guy R. Lefrancois. 1995. Theories of Human Learning (Kro: Kros Report).

Javier, Jeffrey. http://www.azcentral.com/news/articles/2010/12/10/20101210peoria-pilot-teacherevaluation-program.htm.

Khranke, Karl. 1987. Approaches to syllabus Design for Foreign Language Teaching, New Jersey: Prentice Hall Inc.

Mulyasa. E. 2002. Kurikulum Berbasis Kompetensi Dasar, Konsep Karakteristik, Implementasi. PT. Remaja Rosdakarya, Bandung.

Nunan, D. 1989. Designing Task for the Communicative Classroom. Cambridge: Cambridge University Press.

Richard N. Cowell. 1988. Buku Pegangan Para Penulis Paket Belajar (Jakarta: Proyek Pengembangan Pendidikan Tenaga Kependidikan, Depdikbud.

Riccards. http://the apple.monster.com/benefits/articles.

Rossi, Peter H, Freeman, Howard E. 1985. Evaluation. A Systematic Approach. (third Edition). Sage Publications. Icc. Newbury Park, Calofornia, USA.

Saepudin, Asep. 2004. Problematika dan Strategi Peningkatan Mutu Pendidikan Tinggi di Indonesia. Jurnal Teknodik, No. 15/VIII/Desember 2004. Pusat Teknologi Komunikasi dan Informasi Pendidikan Depdiknas.

Sallis, Edward, 2006. Total Quality Management in Education (Manajemen Mutu Pendidikan) Penerbit IRCISOD, Yogyakarta.

Spencer Jr. Lylem and Signe M. Spencer. 1983. Competence Work. Models for Superior Performance. (USA: John Wiley \& Sons, Inc.).

Tomlinson, Brian. 2001. Materials Development in Language Teaching. Cambridge: Cambridge University Press.

Unesco-OECD. 2001. Country Profiles: Working and Labor-Market Conditions of Teachers. Yogyakarta.

Ur, Penny. 1996. A Course in Language Teaching Practice and Theory. Cambridge: Cambridge University Press.

Yuniarsih, Tjutju. 2003. Implementasi Konsep Mutu Terpadu dalam Pendidikan. Jurnal Manajemen dan Sistem Informasi. Bandung. FPIPS UPI Vol 1. No. 2. Januari 2003.

Zainuddin, HM. 2008. Reformasi Pendidikan. Kritik Kurikulum dan Manajemen Berbasis Sekolah. Pustaka Pelajar. Yogyakarta. 